\title{
Special Economic Zone at the Crossroads: The Case of Batam
}

\author{
Adiwan F. Aritenang•
}

\begin{abstract}
The establishment and development of Batam are very much related to Indonesia's development itself. Considering its strategic location, since the 1970s, the Indonesian government has planned and developed Batam to catch economy spillovers from Singapore. The decentralization induces new development paths through critical juncture restructure the institutional setting in the Batam government and innovation of ICT by the Batam Indonesia Free Zone Authority (BIFZA) leaders. These new paths introduce new development trajectories for Batam that has relied on manufacturing and infrastructure for its economic development. The paper analyses the impact of the political economy shift on Batam's economic growth. Using historical institutionalism, the paper argues that the city exhibit urban economy resilience as, despite national politico-economy turbulence, the city creates new opportunities for alternative economic growth channels. The innovation, knowledge accumulation and strong informal ties allow the ICT sector to emerge as the driver of economic growth, adding to the manufacturing sector. This shows the importance of technology adaptation to avoid institutional lock-in and path dependence for local development.
\end{abstract}

\section{Keywords:}

special economic zone; historical institutionalism; ICT.

\section{Introduction}

The fall of the New Order regime in 1998 leads to a regime shift in Indonesia from centralization to decentralization. Decentralization has empowered local governments in political, administrative and fiscal capacities. Given the change toward political and fiscal decentralization, it is crucial to examine the impact on regional development in Indonesia. To examine the effect of the new regime, Batam provides an interesting case study as the city was developed with special policies on infrastructure, tax holidays and investment services, which are found only in the city.
The result was rapid economic growth following the manufacturing industries and population boom between the 1980s and mid2000s. There were only 10 industrial firms with 2,200 workers in the 1970s which had expanded to 564 firms with 157,000 workers in 2000 (Brown, 2004). While economic growth remains high, Batam's economic growth is about $6-7.4 \%$ compared with national growth which is about 5.3\%. Between 2012 and 2015, decentralization has brought Batam into a fragile condition with two unique statuses: (i) as a special economic zone within the City of Batam and (ii) restructuring of the Batam Authority organization structure; that led

\footnotetext{
- Regional and City Planning Program School of Architecture, Planning and Policy Development Institut Teknologi Bandung, Indonesia.

Email: a.aritenang@sappk.itb.ac.id
} 
to conflicting administrative and regional pressures (Aritenang, 2016).

The national government successfully developed Batam Island from a fisherman's island into a thriving regional growth center between the 1970s and 2000s. The island's development has advanced through specificdesigned policies and infrastructure during the New Order regime. After a decade since the issuance of the decentralization law, there are limited studies to examine the progress of Batam and how the island has managed to maintain the development pace it had before decentralization.

Integrating significant political fiscal shift and historical development, Batam provides an important case study to examine the impact of decentralization on regional development for two reasons. First, the complication of institutional arrangements and legal status has brought uncertainty in the city's development. This leads to the lack of recognition of the central government to Batam. In this sense, the city has been seen to be "shrunken" as a "Free Trade Zone" port that is disconnected from the main Economic Centre Connecting Lanes that span across Sumatera (Kumar and Siddique, 2013). Second, despite lack of economic progress over the new regime, Batam remains among the highest GRDP per capita and hosts high-tech industries in Indonesia. Thus, the complex history of Batam development is a unique case of state intervention in local development.

Considering this contrary development under the decentralization regime, this paper aims to examine the lineage and trajectories of Batam's development by looking at the path development of the manufacturing industry and current technological development. This paper adopts the historical institutionalism approach from the comparative political science (Eaton, 2004; Slater \& Simmons, 2010). By using the mix method, the paper examines the impact of decentralization on
Batam's development trajectories with its dual administrator of Batam, BIFZA and local government, that controls SEZ and urban development, respectively.

The paper is organized as follows; the following sections elaborate the theoretical framework and research methods. The fourth and fifth section discusses the research analysis and findings with quantitative analysis and historical institutionalism. The last section provides a research summary.

\section{Theoretical Framework}

This section revisits theories on economic growth and comparative politics to examine the development in Batam. The city was established as an economic growth centre supported with special regulations, legal status, and abundant infrastructure development to strengthen its role to host manufacturing industry.

\section{Decentralization: A form of Historical Institutionalism}

The literature of historical institutionalism mainly explored the relationship between institutions and economic performance North (2005). This paper extends the book by Aritenang (2016) that uses this methodology to explain the institution's role at the district level, by looking at the impact of the state structuring-induced institutional change on regional economic growth.

The literature argues the incentives of development are the underlying determinants of economic performance (North, 2005). These incentives are influenced by the role of formal and informal institutions and enforcement rules in producing polities that reduce transaction costs and institutions that are bound by a belief system (North, 2005). In addition, a successful economic system should be able to survive shocks and changes caused by external development and internal adoption, known as adaptive institutions (North, 2005; Rodríguez-Pose and Storper, 2006). In the 
economic perspective, this is important as the key to long-run growth through the local institutional capacity to adjust and innovate policies (Aritenang, 2016).

The historical institutionalism approach allows to identify regional economic divergence within the economic performance perspective. The property rights and transaction costs within each box differ slightly, indicating variations in institutional arrangements over time. The degree to which property rights are exploited by agents is bound by transaction cost. The belief system consists of the institutional development path that binds the path chosen at a critical juncture; the rate of institutional reinforcement and reproduction determines learning capabilities. This belief system also determines local growth trajectory and institutional adaptability.

The historical institutionalism approach allows the analysis of institutional change and transformation of learning and adaptation, which are channelled through institutional conversion with the presence of new actors who find opportunity in the system because of institutional changes; and the institutional layering where the modification of systems is incorporated into existing structures (Mahoney \& Thelen, 2010; Thelen, 2004). This paper regards this political economic change as the critical juncture, following historical institutionalism literature. To understand how institutional change determines local economic divergence, it is important to observe the institutional adjustments in developmental processes that follow political and economic shocks (Rodríguez-Pose \& Storper, 2006).

The institutional changes in Indonesian took place in the form of decentralization. Indonesian politics has changed rapidly from a relatively stable authoritarian regime to a politico-economy dynamic democracy regime since 2001 (Seymour and Turner, 2002). Decentralization itself was a product of high demand and an attempt to provide alternative administration arrangement to keep Indonesia intact through a democratic government (Alm et al., 2001, p.100). The main reason decentralization received support was the idea that decentralization was necessary to enable resource-rich regions to have more control and thus to avoid national disintegration. However, as has since been observed, the impacts are both economically and politically unpredictable, with increasing regional disparities and persistent demands for regional splitting (pemekaran daerah) (Booth, 2011; Fitriani et al., 2005).

Adopting from the historical institutional approach, there were two factors that led to the critical juncture of regional development in Indonesia. First, the decentralization laws (Undang-Undang) 22/1999 and 25/1999 marked regional autonomy and fiscal decentralization. The decentralization law 22/1999 abolished the hierarchical relationship between the central, provincial and district governments, and empowered the local governments and assembly that are delegated to determine the government organization and political decisions. The law also regulates that decentralization at the provincial level is both the de-concentration and devolution forms. This refers to, in addition to administrating provincial affairs, the provincial government also coordinating the central government's provincial agencies, such as the field administration offices in education, religion and port administration. On the other hand, municipalities (or regional governments) and villages are in the decentralization form of devolution.

Meanwhile, Law 25 regulated the financial relationship between the regional and central governments (Booth, 2003). The local governments are delegated to both revenue and expenditure authorities. In the revenue side, the local governments are entitled to their ownsource revenue (OSR) consisting of tax, levies, and revenue from regional-owned enterprises; and intergovernmental transfer which includes the shared taxes, natural resources revenue 
taxes, general and special allocation funds and regional borrowing. On the expenditure side, the local government is required to plan and execute local budget (APBD), annually. There has also been concern over the limited sources of revenues for district governments (Suwanan and Sulistiani, 2010).

The second factor was the bureaucratic reform driven by the good governance concept. The concept has enhanced the demand for a more responsive and qualified local government. In line with the development of information and communication technology, the e-government (e-gov) emerges as an alternative to strengthen and improve local government public services. The e-gov could be referred as "the use by government agencies of information technologies (such as Wide Area Networks, the Internet, and mobile computing) that have the ability to transform relations with citizens, businesses, and other arms of government" World Bank Group (2017). Furthermore, e-gov could be interpreted as a representation of citizen charter in which the people promote citizen involvement into the state's domain. In particular, e-gov enables citizen advocacy and negotiation, at an individual and communal scale, to accelerate public services (Jati, 2014).

The concept of e-gov refers to the organisation of government services and activities that evolved on the usage of electronic and ICT infrastructure. The e-gov allows the government to adapt logics based on economic thinking of efficiency and effectively achieve technical progress and solve social change. Another important aspect of e-gov is the governance system as the driver of e-gov, rather than the government. Having said this, the e-gov represents dramatic changes in the way government works and thus, it is beyond the implementation of e-gov per se (Behrens, 2012). In Indonesia, the issuance of the President Instruction (Instruksi Presiden) No. $3 / 2003$ that regulates the ICT development to establish the e-gov to support local government services has strengthened the development of ICT utility among the local governments. However, currently, Indonesia's ICT e-gov index rank remains low at 106.

\section{Institutional Change and its Impact to Batam}

The dominant role of central government indicates the significant effect of the institution on economic growth in Batam. The study by Phelps et. al (2014) displays the presence of path's dependence with the innovative social security policy and one-stop services found in Batam which was, in fact, related with the island's exposure with Singapore. In this sense, urban policy development is likely to be imported from neighboring countries, rather than locally-induced policy. The path suggests that the political climate established by the Singapore and Indonesian governments were the main factors that accelerate industrial and economic development in Batam. These industries were established following the intergovernmental cooperation between Indonesia and Singapore, as Singapore's adoption of a regionalisation strategy to achieve fostering higher value-added investment (van Grusven and Hutchinson, 2015).

The importance of spatial proximity to Singapore is seen as the uncertainty whether policies and infrastructure as invested could lead to similar economic growth as in Batam. The island enjoys strong cooperation between multilevel of governments that work closely with industry groups. It is through its infrastructure and the proximity to Singapore that shape the competitive environment in the industrial estates where the firms were able to access into the low-cost environments, leverage on Singapore's infrastructure, management and technological advancement (Yeoh, et al 2004). Looking at these factors, Pepinsky and Widjaya (2011) argue that it is not realistic to expect that competitive pressures could lead other regions to adopt similar policies to recreate Batam's successful policies.

After decentralization, therefore fading 
importance of Batam at the national level. The city was established and developed in a special condition, that is it continued in the current decentralization period. However, at the same time, the establishment of Batam Municipality government indicates that the city has a local authority as with other regions. The complex institutional arrangement is presented in the administrative system with establishing the Regional Council (Dewan Kawasan), a special committee that oversaw the Batam Authority to operate industrial and special economic zone. Another example was the curtailing role of Batam as a national growth engine. The Masterplan for the acceleration and expansion of Indonesia's economic development (Master Plan Percepatan dan Perluasan Pembangunan Ekonomi Indonesia/MP3EI) 2011-2025 issued in 2011 omitted the island as a growth center for the Sumatra Island corridor.

The decentralization also provides regulation complexity in the island's development management. First, the division of authority between BIFZA and the municipal government regulated in Law 53/1999 and Law 23/2014. Second, industries and economic activities in Batam are regulated by Law no.44/2007 and Law no.46/2007 that BIFZA manages permits and infrastructure for industries, both within and outside the industrial zones, the FTZ and is also authorized for industries tax and retribution tariff settings and collection. The laws also allowed the agency authority to manage land ownership and provision in Batam, including permits for non-industrial activities that are administered by the municipal government, such as housing, retail and urban facilities. These laws also authorize BIFZA for investment permits, ICT and infrastructure development.

\section{Methods}

The paper uses mix method analysis to capture the current politico-economy of Batam's development. First, quantitative descriptive analysis presents the changing landscape of sectoral development in the island. Using an LQ index provides a brief sectoral economic contribution to Batam. The LQs with a value greater than one indicate a subsector concentration within the city, while an LQ value of less than one indicates that the area lacks subsector specialization.

$$
\mathrm{LQ}_{\mathrm{i}}^{\mathrm{R}}=\frac{E_{i}^{R} / E^{R}}{E_{i}^{N} / E^{N}}
$$

LQ : Location Quotient or Hoovver-Balassa coefficient

$E_{i}^{R}$ : Number of jobs in subsector in Batam

$\mathrm{E}^{\mathrm{R}}$ : Total number of SMI jobs in Batam

$E_{i}^{N}$ : Number of jobs in the subsector in all identified clusters in Riau Island province

$\mathrm{E}^{\mathrm{N}}$ : Total number of jobs in all identified clusters in Riau Island province

Second, qualitative analysis of historical institutionalism is conducted to explain the above changing economic structure through the analysis of national politico-economy, actor networks, and BIFZA policies. The historical institutionalism approach to analyse the development in Batam adopts the historical institutionalism approach to comparative politics (Mahoney \& Thelen, 2010; Thelen, 2004). First, the paper identifies the critical antecedent institutions that define the political and organizational behavior of the regime. Second, the presence of critical juncture provides new institutional path choices that the society faced. However, at the critical juncture, the society's preferences over new institutional choices, are bounded by the previous knowledge and inherited institutions. Finally, the illustration shows the presence of intervention that influences the progress of regional institutions. There are two sources of intervention: the legacies of previous institutions and the result of institutional learning and adaptation. 


\section{Results and Discussion}

\section{Shifts of Batam Economic Sector}

First, we need to look at the economic structure of Batam city. The city is dominated by Manufacturing, Trade and Finance subsectors that made up to $93 \%$ and $91 \%$ of GRDP in 2001 and 2011. Despite the city's GRDP increase significantly $70 \%$, the contribution of the manufacturing industry declined from $82 \%$ to $60 \%$, while trade sub-sector contribution increased significantly from $5.5 \%$ to $25 \%$.

\section{Table 1.}

Batam GRDP level and growth with constant price in 2001 (2001-2011)

\begin{tabular}{lccc}
\hline & \multicolumn{2}{c}{ GRDP (IDR) } & \multirow{2}{*}{ Growth (\%) } \\
\cline { 2 - 3 } & 2001 & 2011 & \\
\hline Agriculture & $1,174,918$ & $1,870,861$ & 5.92 \\
Construction & $617,400.6$ & $2,122,243$ & 24.37 \\
Finance & 978,290 & $2,059,519$ & 11.05 \\
Manufacturing & $15,597,455$ & $22,239,553$ & 4.25 \\
Mining & $3,407,424$ & $2,140,382$ & -3.71 \\
Service & $453,840,3$ & $1,009,980$ & 12.25 \\
Trade & $1,863,807$ & $10,115,037$ & 44.27 \\
Transportation & $756,606.7$ & $2,010,924$ & 16.57 \\
Utilities & $54,150.87$ & $248,219.7$ & 35.83 \\
\hline Total & $\mathbf{2 4 , 9 0 3 , 8 9 2}$ & $\mathbf{4 3 , 8 1 6 , 7 1 9}$ & 7.59 \\
\hline
\end{tabular}

Source: Batam Statistics Office, 2012
The three main sub-sectors are measured with Location Quotient (LQ) analysis using equation 1 (Figure 1). The graph confirms the GRDP dynamic between the period. The graph shows the impact of decentralization as the manufacturing industry and finance declined gradually, the trade sub-sector has increased rapidly since 2003.

The above phenomenon can be explained as follows. First, the politicization of Batam's economic status throughout the decentralization regime has led to a stagnation of the manufacturing industry and a shift from the finance to the trade sector. This development shift may also be due to the long political debate at the national level that causes both uncertainties on Batam's legal status and jurisdiction quarrel between Batam Industrial Development Authority (BIDA) and local government. The legal status of a free port and zone (FTZ) was finally issued in 2009, almost a decade after the decentralization. The law also solved the territorial boundary conflict between BIDA and local government jurisdiction that states BIDA operates all industrial landscape in Batam including the industrial estate, ports, and

Figure 1.

The LQ of Batam's Main Industry Sub Sectors (2001-2011)

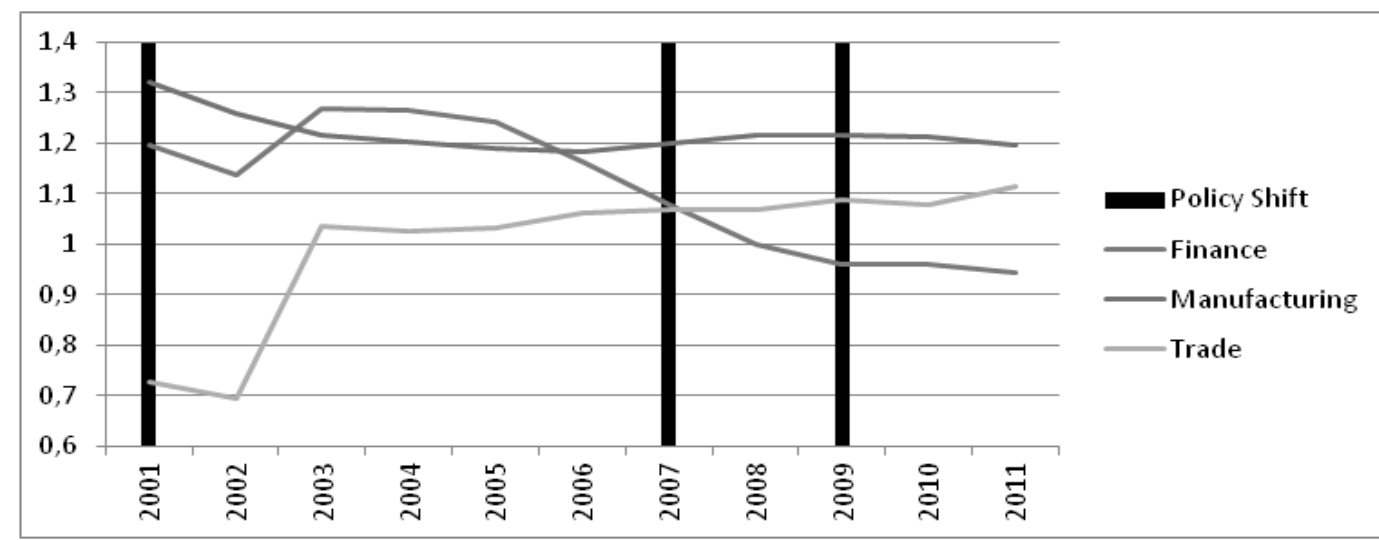

Source: Author's analysis

Notes:

- Implementation of decentralization (Law No. 22/2001)

- The issuance and implementation of Law Free Trade Zone and Free Port (Law No. 44/2007)

- The issuance and implementation of Special Economic Zones (Law No. 39/2009) 
investment. On the other hand, the remaining part of the city under the responsibility of the local government of Batam city, as found in other municipalities and regencies across Indonesia.

Second, the Foreign Direct Investment (FDI) value has fluctuated in recent years from US\$ $374.95 \mathrm{M}$ in 2012 and declined to US\$ $285.18 \mathrm{M}$ in 2014 , before the figure increased to US\$ 474.06 M in 2015. The recent manufacturing industry data shows that FDI in Batam industry is dominated by transport equipment and other transport sectors $(53.59 \%)$ and the chemical and pharmaceutical industry (25.53\%). On the other hand, the FDI country of origin is largely joint countries (54.05\%) followed from Malaysia $(36.79 \%)$ and Singapore (22.29\%).

Third, the trade sector itself has been accelerated with Indonesia's involvement in various free trade agreements (FTAs). In these FTAs, manufacturing sub-sectors found in Batam are sub-sectors that are included in the FTAs, which boost the export value and size. Third, the complicated institutional arrangement is worsened with the changing of the extra-regional institution, where BIDA, which used to be directly under the President's control, is presently coordinated by the Regional Council that is controlled by the Ministerial Council. The chairman and vice chairman of the regional council are the Governor of Riau Island and Batam Mayor, while the Ministerial Council is led by the Ministry of Finance and consist by various ministries. This organisation structure change meant that the BIDA, now transformed as Batam Indonesia Free Zone Authority (BIFZA), is merely a company that runs a free trade zone. Thus, the graph suggests that this limited authority to regulate the island has contracts the manufacturing output.

Finally, in order to explain the above economic structure shift in Batam, we need to understand Batam's relationship with ICT and electronics that has existed for more than three decades. Traditionally, Batam has been one of the electrical and electronics (E\&E) industry's leading centers in Indonesia following the influx of foreign capital as the removal of foreign ownership restrictions on in 1989 (van Grusven and Hutchinson, 2015). During its peak, the island contributed more than $50 \%$ of the country's exports of electronic components and parts before the decline and its lack of 'adaptation'. The paper further argues that these setbacks demonstrate that the trajectory of the E\&E industry in Batam is not robust. Studies have shown that the E\&E industry in Batam has declined in Batam, except the semiconductor branch (Van Grunsven, 2013; van Campenhout and de Graaf, 2013). The paper by Van Grunsven and Hutchinson (2015) shows that the E\&E industry is the trajectory of path 'decay' as employment and investment remained steady. For instance, the survey by Van Grunsven and Hutchinson (2014) on the sector suggest limited progress towards upgrading. In Batam, only a minority of firms have upgraded in a significant way, while most firms continue to produce parts and lack product diversification. In particular, between 1994 and 2012, the EE sector in Batam shifted from consumer electronics to the electronic components branch domination. The number of companies from the latter branch increased from 3 companies (23\%) to 8 companies (58\%), respectively. While the telecom service branch declined from two companies (AT\&T and Telkomsel) in 1994 to become none in 2012.

\section{The Path Dependence of Batam: An Historical Institutionalism Approach}

To understand the above phenomenon, we conduct an Historical Institutionalism Approach in this subsection. This qualitative analysis emphasis on the path dependence of institutions in Batam. The historical institutionalism framework is shown in Figure 2. The framework allows path dependence analysis of ICT with regard to the economic and political conditions in Batam and at the 
Figure 2.

Historical Institutions Research Framework



Source: Adapted from Aritenang (2016)

national level. Furthermore, the model also allows any political and economic events that occurred following an institutional shock and feedbacks that the institution received.

\section{The Antecedent Institutions and Critical Juncture: The Order Regime}

Industrial activities in Batam began with the establishment of the logistics base for Indonesia Oil and Gas Company (PERTAMINA) as the location for oil mining warehouse and distribution route under the wing of Ibnu Sutowo, the then-chairman of the Indonesian state-owned oil company, PERTAMINA, in the early 1970s. The company was the strongest and most successful company in the nation due to abundant oil production and favorable oil prices. After taking over the Island from PERTAMINA, Dr. Habibie envisaged Batam's development based on infrastructure and the manufacturing industry using the "balloon theory." This scheme predicts that Singapore needed Batam to take care of the production overspill from its heavily burdened industry to prevent it bursting like a balloon.

The combination of policy and strategic location, the government established the region as an industrial zone and the Batam Industrial Development Agency (BIDA) as the regional administrator in 1973. The Indonesian government has shifted Batam islands economic status as a bonded zone throughout the 1970s to the 2000s and later on as a Free Trade Zone (FTZ) in 2007. Batam City has been developed as a centre for industrial, service and tourism activities, taking advantage of the geographical proximity to Singapore (Firman, et al. 2007). Furthermore, the government to government (G2G) cooperation supports that Batam's development takes place in the establishment of Batamindo, the first and largest industrial park. The estate was developed by Sembawang, a prominent industrial park developer from Singapore. The result is that the city experienced 
a high influx of population from various regions in Indonesia, notably Java.

The economy and manufacturing industry in Batam has been dominantly influenced by the national politico-economy (Kumar and Siddique, 2013). The main driver of manufacturing industry development in Batam was the political cooperation between Indonesia and Singapore to invest in the island. Through BIDA, the Indonesian government was responsible for designating locations, types of industries and special regulations in Batam. Furthermore, the central government promotes various manufacturing industries and foreign investments into the industrial estate. The investment began with the industrial park, Batam Industrial Park, with facilities and infrastructure for low-cost seeking MNCs from Singapore and other countries. In this sense, Singapore took an important and leading role in developing an industrial estate and also a marketing role with Batam as a preferred location for MNCs from Singapore (Kumar \& Siddique, 2013, p. 69).

The outcome was that Batam could be seen as Singapore's manufacturing base, which signifies the country's role in the economic progress of Batam. This is evident in how the Singapore government-linked companies co-operated with private Batam partners to establish industrial parks in the 1990s. Overall, there are more than twenty industrial estates across Batam mainly found in Batam Centre, Batu Ampar, and Muka Kuning sub-districts that offers facilities ranging from ready-tobuild lot parcels to buildings with complete facilities. The industry estates also provide a complete package including the processing of permits and licenses to relevant authorities and recruitment of labor, with some labor dormitories also provided. In a bigger picture, this leads to an increasing number of MNCs from the country that was followed by other investors to set up industrial estates from other countries such as Taiwanese.
Firms located in the industrial estate was crucial to create job and manufacturing activities, both between themselves and informal networks outside the estates (Kumar \& Siddique, 2013, p. 76). However, the book further suggests that industries in Batam remain low technology and low value-added. For instance, between 1998 and 2006, the nominal output per worker fluctuated in Batam with a consistent decline after 2000 .

However, the success of this innovation relies very much on institutional arrangements that determine present policies and actor networks. The presence of research institutions and scholars network under B.J. Habibie authority. He established technology institutions including the Agency for Assessment and Application of Technology (Badan Pengkajian dan Penerapan Teknologi/ BPPT), Strategic Industry Management Agency (Badan Pengelola Industri Strategies/BPIS), in addition to already existing institutions such as the Indonesian Institute of Sciences (Lembaga Ilmu Pengetahuan Indonesia/LIPI), National Nuclear Energy Agency (Badan Tenaga Nuklir Nasional/BATAN) and BIFZA.

Following his appointment to manage Batam by President Soeharto, Habibie treats Batam development as an engineering project to lay the foundations of a new industrial location. Crucial for the development of technological networks, Habibie established interactions among employers across technological-based organisations that he led. For instance, a large number of new employers for BIFZA were recruited through $\mathrm{BPPT}$, and engineers from BPPT were the designer and construction expertise of the six Barelang (Batam, Rempang, and Galang) bridges that connect Batam with other seven smaller islands. Through some interviews, it was also revealed that some of these "BPPT recruits" had never worked in BPPT, but instead had worked in BIFZA throughout their professional career. This allows the island to became an experimental 
location for Habibie's engineers to plan and establish the technological-based socioeconomic landscape (Amir, 2013). Habibie allocated people in one institution to support projects in other institution to disseminate and deepen technological networks through staff placement between these institutions. The result was seen particularly in the 1990s and 2000s where many of the technology scientists and managers that were reallocated strengthen the cooperation and collaboration between their original and new institution. For instance, the BIFZA has been historically receiving a number of BPPT employees since the 1980s.

\section{Institutional Change and Reproduction: The Decentralization Period}

The recent book on Batam by Kumar and Siddique (2013) suggests that political and bureaucratic forces in this period have produced institutions and forms of leadership that hinder progress through poor decision making and policy implementation. During this period, there was a sustaining effect of AFC that the manufacturing industry in Indonesia fails to return to its pre-crisis growth level and in fact, shows a declining growth in industrial output, employment, and production. The average level of productivity in Indonesia is very low compared with Japan, Singapore, Malaysia, and Thailand. The paper also argues that in the current period, industrial policy has shifted from exports to policies that support domestic sources of growth in services and capital and resource-intensive products. Consequently, the gloomy picture of the national manufacturing industry applies in Batam.

During the stage of critical juncture of Decentralization implementation, there were two events that shaped the trajectories of Batam development. First, the BIDA establishment of Batam Intelligence Island (BII) as a master plan that exhibits the grand strategies of ICT development empowered by broadband Internet and local telecommunication infrastructure to enhance Batam competitive advantages. The BII was included in the fiveyear plan 2001-2005 on the Information and Communication technology policy under the President's Instruction No. 6/2001. The initiative was the government's pilot project of an ICT application for private sector sectors that implement comprehensive e-gov, e-business, and e-public infrastructure services. While the decentralization in 2001 changes the institutional arrangement of local government across Indonesia that providesa momentum for BIFZA to improve ICT capabilities and services.

The Batam e-gov shows the importance of coordination between line ministries with local authority to induce regulations that reduce logistic cost. The advancement in the Batam e-gov system was that it already allows investors to apply business permits and land lease license services. Thus, this E-gov and ICT services by BIFZA was a frontrunner in technological advancement compared with other local governments and national capacities in the early 2000s. Literature suggests that at the time, there is no single national, centrallycoordinated e-Government implementation in Indonesia, such as Jakarta and Jogjakarta that initiated much later, in 2004 and 2009, respectively (Salahuddin and Rusli, 2005; Wibowo et al. 2014; Wulandari and El Anshori, 2012) shows.

Interestingly, Batam's e-gov success also preceded the central government. The State Ministry of Communication and Information is currently holding a "centralised guidance" and "autonomy planning and implementation" with focus on establishing local ICT Human Resources and integrated local ICT development. The shortfall of authority held by the State Ministry of Communication and Information the government institution responsible for the planning and implementation of e-government was due to the separation of Telecommunications as an SOE that is under the responsibility of the SOE Ministry. This led to inadequate policies 
and practices on convergent e-gov planning and implementation. However, there were numerous Working Groups formed under different groups such as the TKTI secretariat has formed separate Working Groups to handle Infrastructure, e-Government, e-Commerce, e-Health, and Business Model and Budgeting.

Second, the institutional arrangement of the Batam authority in which BIDA authority, as a single agency in government affairs and economic welfare, were transferred to the newly established Batam municipality government. This occurred during the institutional arrangement that was shaped by the prolonged national politics. The BIDA was challenged with the regional splitting that occurred across the country. The decentralization Law 22/1999 was interpreted to establish new provinces and districts that led to the booming number of regions. The process to share governmental responsibilities between the two organizations took almost a decade as it related to Batam's economy and political strategic position at the national level. BIDA was transformed as BIFZA with the issuance of Government Regulation 46/2007 on the Free Trade and Port Zone. The main difference with the previous organizational structure is that BIFZA is an organization that is established and coordinated by the Regional Council that is responsible to the Ministerial Council on Free Trade and Port Zone, while BIDA is directly coordinated by the President. Hence, this organization-restructuring weakened Batam's economic and political power at the national level.

\section{Trajectories of Batam Development: The ICT Sector}

There are three trajectories of ICT development in Batam. First, the Batam authority is the frontrunner of ICT and electronic government (e-gov) services at the local level. The government implemented the BII as the Datacenter and IT Solution office.
The office is a division under the BIFZA that has provided ICT facilities for government and MNCs in Batam since 2008. Presently, the centre hosted the government institution's Disaster Recovery Centre and enhances efficiency, security, the reliability of BIFZA's ICT services to private sector activities including industries, shipping, and tourism. The centre has 14 government institutions and two private company clients (BIFZA, 2016). The location's proximity from Singapore, as the main Fiber Optic (FO) network in the world, allows the center to be an FO hub between Indonesia and Asia Pacific. The Batam e-gov development has improved services in trade and logistic-related process (Irawan et al., 2012). The roadmap shows that ICT development is crucial to support industrial development (electronic and electrical, tourism, shipyard, and oil refining) and logistics hub (transhipment) (BIFZA, 2014). Hence, the implementation of ICT services would be an important development tool not only for Batam, but also Indonesia as one of the main obstacles in inter-island mobility is the high cost of transportation and lack of spatial integration policies (Sandee et al., 2014).

Furthermore, the BII allows students access to e-learning across and beyond Batam. The study by Widyastuti et al. (2013) shows that the cooperation between the IT center and the local government has enabled cross e-learning between schools, whereas students in hinterland Batam access study materials that were developed and shared by teachers from mainland schools. Furthermore, the paper shows that the process was also supported by the mobile device (m-learning) that enables easier access for students and teachers to implement e-learning with asynchronous (p. 6). On a wider scale, the center also hosts ICT training for other local governments and is appointed by the Ministry of Home Affairs (MoHA) to host the mirror server of Indonesia's electronic identity card (Elektronik Kartu Tanda Penduduk/E-KTP). 
Second, the technocrat networks internalized technological advancement developed in BPPT and other institutions. The cooperation between BPPT and BIFZA in 2013 shows that the engineering network that Habibie established two decades earlier remains today. The cooperation between Ipteknet, an Internet research center in BPPT, and BIFZA to develop the ICT since the launch of Batam ICT roadmap. The result of this cooperation, among other things, we the establishment of the IT center, owned by the BIFZA, as a host for shared service (Web hosting, Mail Hosting Storage), dedicated service (server, virtual server), location service (room, rack), and disaster recovery (DRC, DC management, link) (BIFZA, 2014, p. 20). Recently, the cooperation between BIFZA and BPPT is the development of Batam Techno Park (BTP). BPPT's long experience in technology research and advancement allows the agency to provide management training on institutional setup, SOP, and performance measurement for technology-based activities (Batam, 2013). The BTP is one of the Technoparks, a nation's program to accelerate technology capacities by adopting cluster development emphasizing human capital and technological advancement. The human capital would be strengthened through intense communication and interaction between policymakers, researchers from national research centers and academics, and private sector research centers. On the other hand, the BTP focuses on the ICT sector, especially the electronics and animation, that has progressed vigorously in Batam.

Thirdly, the ICT development also responded to regional and global industry competition. The institutional lock-in of actor networks and knowledge accumulation in the ICT sector, spatial proximity and intense network with industries in Singapore and Malaysia, has led the Island as the foremost advanced region in Indonesia to support its manufacturing and trade sectors. The Batam
ICT roadmap attempts to fulfill private sector's ICT requirements to support their business. The large proportion of foreign investors from Japan and Singapore also accelerate the ICT adoption in Batam as their respective governments are committed to supporting the private sector in Batam. The ICT services for urban development including issuing business permits and licenses in industry and trade, environment, and tourism. The Batam city government sees the services $\mathrm{s}$ important to provide one-stop services (OSS) for licensing and investment permits. The main obstacle was the unsupportive legislative side to allow the OSS unit to be an independent office within the local government that hinders its capacity to accelerate more efficient, effective, and integrated system in ICT services (Sihombing, 2012).

\section{Conclusion}

Institutional arrangements at the national level determine local development process. The politico-economy shift resulting from decentralization led the local governments to accelerate local economic development and welfare. Despite there being little evidence of decentralization significantly improving public services (Hill, 2014), this paper shows that decentralization provides the institutional arrangements to destruct the on-going economic development. The manufacturing industry and finance sectors declined gradually, while the finance sub-sector declined significantly, the trade sub-sector increased sharply. At the same time, the continuity of politiciation of Batam's economic status and complicated institutional arrangement intensifies the shift of extraregional institution which has led to poor law and economic climate for industry investment.

This paper shows that path dependence of local institutions plays an important role in the Batam development. The unintended consequences of institutional lock-in and knowledge accumulation is with the emergence 
of the ICT sector, rather than the main sector, the manufacturing industry. There is lack of evidence between sub-sector EE and ICT in Batam, as the figure shows declining trend of sub-sector EE in Batam. On the other hand, the emergence of ICT in Batam that relies on the expertise of ICT through knowledge spillover and research network as a result of strong ties with BPPT.

The paper argues two critical events that shape economic development. First, visionary leaders and innovative institutions accelerate the development. The BIFZA status as a central government agency and strong ties with various central government institutions also play an important role in providing the basic infrastructure as a backbone for the early economic development. This finding demonstrates that the required regional innovation system for local development, unfortunately, could not be expected to be induced by the provincial and local government as the incentive structure under decentralization are not rewarded (Van Grunsven and Hutchinson, 2015). Thus, the paper further suggested that historical institutions and path dependence are important for local development trajectories.

Secondly, the geographical proximity with Singapore and a large number of MNCs in the island also provide important demand and feedback. As decentralization increases intergovernmental and inter-regional competition, the advancement of ICT in Batam has attracted an abundance of foreign investments and multinational companies (MNCs), which reflects Batam's competitive advantage over other regions. As a result, location advantage of spatial proximity with Singapore has allowed Batam to develop as an economic growth center for Indonesia (Kumar and Siddique, 2013). The Singaporean investment in industrial parks initiates economic activity in the island. As proximity to key trade routes determines access to economic resources and transportation hub,
Batam has been developed to attract investment in manufacturing. Following this policy, the local government has been exposed to more effective and economic-oriented policies through cooperation and networks with neighboring countries such as Malaysia and Singapore. In this sense, geographical location also plays an important role in institutional setting. Proximity to an advanced industrial country provides the opportunity to attract investment through the inexpensive land and labor that allows the city to take advantage of the spillover from Singapore (Yeoh, et al., 2008). As such, it would be difficult to adopt similar business-friendly regulatory exemptions and special policies in Batam to other regions in Indonesia (Pepinsky and Wihardja, 2011).

The paper has highlighted the two important factors for the emergence of ICT in Batam, which is the historical path of innovative policies since the pre-decentralization period and the necessity to respond to industrial needs in the form of e-gov and one-stop services. The implication of this research are that technology adaptation is crucial for local economic development to avoid institutional lock-in and path dependence.

\section{References}

Alm, J., Aten, R.H., \& Bahl, B., (2001). Can Indonesia decentralise successfully? Plans, problems and prospects. Bulletin of Indonesian Economic Studies, 37(1), 83-102. doi: 10.1080/000749101300046537

Amir, S. (2013). The technological state in indonesia: The co-constitution of high technology and authoritarian politics. London and New York: Routledge.

Aritenang, A. F. (2016). The impact of state restructuring on Indonesia's regional economic convergence. Singapore: ISEAS Publishing

Behrens, C. (2012). Success factors for An E-government strategy: Austrian experiences, Indonesian challenges. Journal of Government and Politics, 3(1), 29-44. 
BIFZA. (2014). Pengembangan FTZ dan Global Value Chain Batam Bin Karimun Kelembagaan dan Infrastruktur. Urban Magz. Batam: BIFZA.

BIFZA. (2016). Development progress of Batam report volume XXIX. Batam: BIFZA.

Booth, A. (2003). Decentralization and poverty alleviation in Indonesia. Environment and Planning C: Government and Policy, 21(2), 181-202. doi: 10.1068/c0127

Booth, A. (2011). Splitting, splitting and splitting again: A brief history of the development of regional government in Indonesia since independence. Bijdragen tot de taal-, land-en volkenkundel Journal of the Humanities and Social Sciences of Southeast Asia, 167(1), 31-59. doi: 10.1163/22134379-90003601

Brown, I. (2004). The Territories of Indonesia. London: Routledge.

Eaton, K. (2004). Designing subnational institutions. Comparative Political Studies, 37(2), 218-244.

Firman, T., Kombaitan, B., \& Pradono, P. (2007). The dynamics of Indonesia's urbanisation, 1980-2006. Urban Policy and Research, 25(4), 433-454. doi: 10.1080/08111140701540752

Fitrani, F., Hofman, B. \& Kaiser, K. (2005). Unity in diversity? The creation of new local governments in a decentralising Indonesia. Bulletin of Indonesian Economic Studies, 41(1), 57-79. doi: 10.1080/00074910500072690

Grunsven, L. v. (2013). Singapore's ICT Industry: An evolutionary perspective. In P. Cooke, G. Searle, \& K. O'Connor (Eds.). The Economic Geography of the IT Industry in The Asia Pacific Region. London: Routledge.

Grunsven, L. v., \& Hutchinson, F.E. (2014). The evolution of the electronics industry in the SIJORI Cross-Border Region. Singapore: ISEAS Economics Working Paper.

Hill, H. (2014). An introduction to the issues. In H. Hill (Eds.), Regional Dynamics in a Decentralized Indonesia (pp. 1-24). Singapore: ISEAS Publishing.

Irawan, H., Suhardi, S., \& Sofia, A. (2012). IT value creating in Indonesian local government: A service model. In H. Handra, B. Resosudarmo, A. Yusuf, E. Elfindri, \& E. Yonnedi (Eds.), Regional development and finances: Challenges for expanding and financing public services. Padang: Andalas University Press.

Jati, W.R. (2014). Kewargaan inklusif sebagai paradigma alternatif pelayanan publik. Jurnal Ilmu Sosial dan Ilmu Politik, 18(1), 66-79.

Kleibert, J. M. (2013). Strategic coupling in 'next wave cities': Local institutional actors and the offshore service sector in the Philippines. Singapore Journal Tropical Geography, 35(2), 245-260.

Kumar, S., \& Siddique, S. (2013). Batam Whose Hinterland? The Influence of Politics on Development ( $1^{\text {st }}$ Ed.). Singapore: Select Publications.

Mahoney, J., \& Thelen, K. (2010). Explaining institutional change: ambiguity, agency, and power. Cambridge: Cambridge University Press.

North, D.C. (2010). Understanding the process of economic change. Princeton, N.J: Princeton University Press.

Pepinsky, T. B. \& Wihardja, M. M. (2011). Decentralization and Economic Performance in Indonesia. Journal of East Asian Studies, 11(3), 337-371. doi: 10.1017/s1598240800007372

Phelps, N.A., Bunnell, T., Miller, M.A., \& Taylor, J. (2014). Urban inter-referencing within and beyond a decentralized Indonesia. Cities, 39, 37-49. doi: 10.1016/j.cities.2014.02.004

Rodríguez-Pose, A., \& Storper, M. (2006). Better rules or stronger communities? on the social foundations of institutional change and its economic effects. Economic Geography, 82(1), 1-25.

Salahuddin, M., \& Rusli, A. (2005). Information systems planning for e-government in Indonesia. Presented at the The Second International Conference on Innovations in Information Technology. Dubai: UAE. Sandee, H., Nurridzki, N., \& Dipo, M. (2014). Challenges of implementing logistics reform 
in Indonesia. In H. Hill (Eds.), Regional Dynamics in a Decentralized Indonesia. (pp. 386). Singapore: ISEAS.

Seymour, R., and Turner, S. (2002). Otonomi Daerah: Indonesia's decentralization experiment. Journal of Asian Studies, 4(2), 33-51

Sihombing, E.M. (2012). An analysis of business licensing policy implementation of Batam's One Stop Service (OSS) and lessons learned from Singapore's Online Business Licensing Service (OBLS). Jurnal Ilmiah Administrasi Publik, 13(2), 265-277.

Slater, D., \& Simmons, E. (2010). Informative Regress: Critical Antecedents in Comparative Politics. Comparative Political Studies, 43(7), 886 -917.

Suwanan, A.F, \& Sulistiani, E.H. (2010). Fiscal Decentralization and regional disparities in Indonesia: dynamic panel evidence. In D. Priyarsono \& E. Rustiadi (Eds.), Regional Development in Indonesia. Bogor: Crestpent Press.

Thelen, K. (2004). How institutions evolve: the political economy of skills in Germany, Britain, the United States, and Japan ( $1^{\text {st }}$ ed.). Cambridge: Cambridge University Press. van Campenhout, M. \& de Graaf, J. R. (2013). In search for a silver lining: the evolution of the $E \mathcal{E} E$ industry of Batam (Master Economic Geography Thesis). Netherlands: Department of Human Geography and
Planning, Faculty of Geosciences University of Utrecht.

van Grunsven, L., \& Hutchinson, F.E. (2015). The evolution of the electronics industry On Batam Island (Riau Islands Province, Indonesia): an evolutionary trajectory contributing to regional resilience? GeoJournal, 82(3), 475-492. doi:10.1007/ s10708-015-9692-9

Wibowo, D.S., Abdullah, I., \& Darwin, M. (2014). The Growth of E-Government in the Government of Yogjakarta City. Journal of Government and Politics, 5(1), 32-48.

Widyastuti, H., Mulyaningtyas, D., \& Brajawidagda, U. (2013). E-learning readiness in Hinterland of Batam. Presented at the The Second International Conference on Knowledge creation and Intelligent Computing. Bali: KCIC.

World Bank. (2017). Brief: e-Government. Retrieved June 9, 2017 from http://www.worldbank.org/ en/topic/ict/brief/e-gov-resources\#egov.

Wulandari, F. R., \& El Anshori, Y. T. (2012). Optimizing public service through e-gov services: the case of public service in South Jakarta Municipality. Journal of Government and Politics, 3(2), 369-390.

Yeoh, C., Lim, D., \& Kwan, A. (2004). Regional cooperation and low-cost investment enclaves: an empirical study of Singapore's industrial parks in Riau Indonesia. Journal of Asia-Pacific Business, 5(4), 43-65. 